ISSN 0103-8478

\title{
Breeding full-sib families of sugar cane using selection index
}

\section{Melhoramento em famílias de irmãos-completos de cana-de-açúcar usando índices de seleção}

\author{
Livia Marcon Almeida ${ }^{\mathrm{I}}$ Alexandre Pio Viana ${ }^{\mathrm{I}}$ Antônio Teixeira do Amaral Júnior ${ }^{\mathrm{I}}$ \\ Josil de Barros Carneiro Júnior ${ }^{\text {II }}$
}

\section{ABSTRACT}

An experiment with families belonging to the first selection stage (T1) of the Sugar Cane Breeding Program (PMGCA) of the Universidade Federal Rural do Rio de Janeiro (UFRRJ)/RIDESA was carried out in the Plant Disa, located in the municipality of Conceição da Barra-ES, in 2006, aiming to evaluate families, for the selection of superior plants for the later stages of the breeding program of the culture. Sixty-eight full-sib families and three genotypes considered standards with potential recommendation for the area under study were evaluated. The experiment was arranged in a statistical randomized block design, in which the families were grouped into four sets. Each set had four replicates and one hundred seedlings per plot, with spacing of 0.5 meters between plants and 1.40 between rows. The evaluations were conducted during two growing seasons, corresponding to the first and second ratoon, 2008 and 2009, respectively. The traits stem diameter $(D M C)$, total weight of the plot $(P)$, number of stems $(N C)$ Brix of the lower stem (Brix PE) and Brix of the upper stem (Brix $P T)$ were assessed. All traits were significant for the genotypes, by the F test $(P<0.01)$, in joint analyses of environments, which reveals significant differences between families. The values found in this study for the genetic variation coefficient $\left(C V_{g}\right)$ indicate great potential for success in breeding programs targeting at the selection of the traits evaluated. The highest gains were achieved when the indices of Smith and Hazel and Mulamba and Mock were used, which allowed simultaneous superior gains in all traits for the best families.

Key words: sugar cane, family selection, selection index.

RESUMO

Foi instalado, em 2006, na Usina Disa, Municipio de Conceição da Barra-ES, um ensaio de famílias pertencentes a primeira fase de seleção (T1) do Programa de Melhoramento Genético da Cana-de-Açúcar (PMGCA) da Universidade Federal Rural do Rio de Janeiro (UFRRJ)/ RIDESA, com o objetivo de avaliar famílias, visando à seleção de plantas superiores para as fases posteriores do programa de melhoramento genético da cultura. Foram avaliadas 68 familias de irmãos-completos e mais três genótipos considerados padrões, com potencial de recomendação para a região avaliada. O delineamento estatístico utilizado foi em blocos ao acaso, no qual as famílias foram agrupadas em quatro sets, cada qual com quatro repetições e cem seedlings por parcela, espaçadas a 0,5 metros entre plantas e 1,40 metros entre linhas. As avaliações foram efetuadas durante duas safras agricolas, correspondentes a primeira e a segunda soca, 2008 e 2009, respectivamente, sendo avaliadas as características diâmetro médio do colmo $(D M C)$, peso total da parcela $(P)$, número de colmos (NC), Brix da parte inferior do colmo (Brix PE) e Brix da parte superior do colmo (Brix PT). Todas as características foram significativas para famílias avaliadas, pelo teste $F(P<0,01)$ nas análises conjuntas dos ambientes, demonstrando haver diferenças significativas entre as famílias. Os valores encontrados, no presente estudo, para o parâmetro genético coeficiente de variação genético $\left(C V_{g}\right)$, indicam grandes possibilidades de sucesso neste programa de melhoramento visando à seleção para as características avaliadas, sendo atribuidos os maiores ganhos genéticos quando utilizados os índices de Smith e Hazel e Mulamba e Mock, os quais permitiram ganhos simultâneos superiores em todas as características avaliadas para as melhores familias.

Palavras-chave: cana-de-açúcar, seleção de famílias, indice de seleção.

\section{INTRODUCTION}

Sugar cane is one of the most important species cultivated in the tropics and subtropics. In Brazil, it's of great economic and environmental significance. In 2012/2013, sugar cane occupied a total crop area of 8.527 million hectares, and provided a

'Universidade Estadual do Norte Fluminense Darcy Ribeiro (UENF), 28013-602, Campos dos Goytacazes, RJ, Brasil. E-mail: pirapora@uenf.br. *Autor para correspondência.

IIUniversidade Federal Rural do Rio de Janeiro (UFRRJ), Campos dos Goytacazes, RJ, Brasil. 
total volume of 596,630.20 million tones to the sugar and alcohol sector, while 72.83 million tons were used in the manufacture of "cachaça", animal feed and for the of seeds and other purposes, according to data from the Companhia Nacional de Abastecimento (CONAB, 2012) (National Supply Company).

A large number of clones are evaluated every year, in sugar cane breeding programs, in experiments conducted in different harvests, seasons and regions. It has been increasingly difficult to select the best genotypes phenotypically. Thus, the use of accurate methods of statistical analysis is necessary to ensure greater reliability in the selection process.

There are some methods of simultaneous selection (VIANA et al., 2012) that seek for efficiently achieving genetic gains in several traits. This selection indices associate information pertain to several traits of agronomic interest and use previously established economic weights, as well as genotypic and phenotypic variances of each trait, and their covariances between each pair of traits, which provides gains for several traits in a single selection program.

Breeding programs have been dynamic and have tested some proposals of changes, always seeking to improve the efficiency of the selection process and facilitate assessments. Thus, researchers have proposed new methods of selection, including the incorporation of recurrent selection and family selection.

The selection of families is an alternative to improve the efficiency of mass selection in sugar cane. The use of families increases the chances for identifying superior clones and improving the efficiency in the use of the resources available for conducting the sugar cane breeding program (BARBOSA et al., 2005).

In this type of evaluation, superior families are selected, as well as superior individuals within each family. Thus, families are evaluated in trials with replication, whose plots were composed of individuals that have not been cloned yet (seedlings), which would provide information on the genetic value of the families assessed.

The selection of families can be adopted when the traits for selection present low heritability, such as the selection for sugar cane yield. This procedure consists in selecting the best families discarding the worst, since selection in families with higher genotypic values tends to be more effective to indicate a higher proportion of promising genotypes.

The identification of families capable of producing superior genotypes is highly desirable to develop new varieties of sugar cane, especially considering a relatively long time for its launching.
SINGH et al. (1981) reported that the adoption of family selection benefits sugar cane breeding programs because it provides important information to determine the genotypic value of the crosses and identifies genotypes and potential elite clones for new crosses.

SKINNER et al. (1987) also reported that the study of families can help predict superior crosses, and efforts can be concentrated on the most promising crosses, which may substantially increase the chances of selecting elite clones. COX \& HOGART (1993) report that the selection scheme between and within families in sugar cane tends to be more efficient than the method of selecting families alone. Few studies employing selection indices in sugar cane are found in literature (PILLAI \& ETHIRAJAN, 1993). These studies are based on genetic parameters and phenotypic averages obtained by the method of analysis of variance.

Selection indices have been widely used in crops such as popcorn (DAROS et al., 2004 and AMARAL JR., et al., 2010); common corn (GRANATE, 2001); yellow passion fruit (SILVA et al., 2009) and papaya (SILVA et al., 2008). The genetic gains were predicted with satisfactory accuracy in all applications, which led to an appropriate performance of breeding programs for the cultures assessed.

Therefore, this study aimed to select the best families assessed in stage T1 of the RIDESA/ UFRRJ breeding program, with the estimation of genetic parameters and use of selection indices to indicate new genotypes for the continuation of the program.

\section{MATERIAL AND METHODS}

\section{Composition of the experiment}

An experiment was carried out in the area of the Plant Disa, municipality of Conceição da BarraES, in February 2006, using families belonging to the first selection stage (T1) of the Sugar Cane Breeding Program (PMGCA) of the University Federal Rural do Rio de Janeiro (UFRRJ)/Inter-University Network for the Development of Sugar and Alcohol Industry (RIDESA) (SILVEIRA et al., 2012), in partnership with the Universidade Estadual do Norte Fluminense Darcy Ribeiro.

The families used in this study were sampled from crosses carried out at the Experimental Station of Serra do Ouro (BARBOSA et al., 2002), in the municipality of Murici, in the state of Alagoas. Samples were removed from 68 biparental crosses (full-sib) of this experiment. 
The experiment was composed of 68 families and three standard cultivars (RB 867515, RB 72454 and RB 835486), arranged in a randomized block design, in which the progenies and controls (treatments) were grouped into four sets that formed the treatment groups. Each of them had four replicates and one hundred seedlings per plot, with spacing of $0.50 \mathrm{~m}$ between plants and $1.40 \mathrm{~m}$ between rows. All the genotypes were used for the statistical analysis.

\section{Evaluation of the experiment}

Cane-plant cutting was held in march 2007 and no evaluations were performed. All assessments of families and plants within families were performed during the first and second ratoon, in 2008 and 2009 , between and within families (by phenotyping individuals from each family).

The following traits were evaluated at harvest time: average stem diameter (DMC): measured with a caliper. The readings were taken in the center of the internode, located in the average stem length. Five readings were carried out at random by observation (seedling), considering the average value. The DMC was measured in both agricultural years (2008 and 2009); Content of total soluble solids - Brix (\%) determined by a field refractometer with five random measurements, considering the average value. Measurements were made on the lower stem - (lower third -Brix PE) and upper stem (upper third - Brix PT). Both traits were measured in both years (2008 and 2009); Weight of stem (P): measured by weighing, in kilograms, all stems present in all lines of the plot, using a dynamometer. This trait was measured only in the first growing season (2008); Number of stems (NC): counting of the total number of stems of the clumps analyzed. This trait was measured only in the second agricultural year (2009);

\section{Statistical analysis}

Analyses of variance were carried out for each trait analyzed to obtain the average square values of the sources of variation involved and the significance of each of them, besides the coefficients of variation, which was followed by the statistical model, arranged in randomized block design, in sets: $Y_{i j k l}=\mu+E_{i}+S_{j}+E S_{i j}+R / E S_{i j k}+G / S_{j l}+E G / S_{i j l}+e_{i j k l}$,

where: $\mu$ : experimental average; $\mathrm{E}_{\mathrm{i}}$ : fixed effect of the i-th environment; $S_{j}$ : effect of the j-th 'set', $\operatorname{NID}\left(0, \sigma^{2}\right) ; \mathrm{ES}_{\mathrm{ij}}$ : effect of the interaction between environments and 'sets' NID $\left(0, \sigma^{2}\right)$; R/ $\mathrm{ES}_{\mathrm{ijk}}$ : effect of the k-th replication within the interaction between the $\mathrm{i}$-th environment and the $\mathrm{j}$-th 'set'; $\mathrm{G} / \mathrm{S}_{\mathrm{j} 1}$ : effect of the 1-th genotype within the $\mathrm{j}$-th 'set'; EG/S $\mathrm{S}_{\mathrm{ijl}}$ : effect of the interaction between environments and genotypes within the $\mathrm{j}$-th 'set'; and ${ }_{\mathrm{ijkl}}$ : experimental error, $\operatorname{NID}\left(0, \sigma^{2}\right)$.

Based on the values of expected average squares, the variance components were estimated: Genotypic variance: $\sigma_{g}^{2}=\frac{(Q M G-Q M R)}{e r}$, Phenotypic Variance: $\sigma_{f}^{2}=\frac{Q M R}{e r}$, Heritability based on the average of families: $h^{2}=\frac{\sigma_{g}^{2}}{\sigma_{f}^{2}}$, Genetic coefficient of variation: $C V_{g}(\%)=100\left(\sqrt{\frac{\sigma_{g}^{2}}{\bar{X}}}\right)$, Variation index: $I_{v}()=100\left(\frac{C V_{g}}{C V_{e}}\right)$, Where: QMG = average square of genotypes; QMR = average square of the residue; $r=$ replication; $\mathrm{e}=$ environment.

Different selection indices were tested for the selection of 21 superior families. In computater analysis, weights were given to each trait analyzed, which showed significant differences among genotypes, by the F test, in the analysis of variance. These weights were chosen at random by attempts, focusing on more favorable gains for each trait under study, though.

The following economic weights were used in the selection indices: genotypic standard deviation, genotypic coefficient of variation, index of variation, heritability and weights assigned per attempt.

It was used the following indices, as described in (CRUZ et al., 2004): Index of Smith and Hazel: This selection index was designed as a linear function of the phenotypic values observed in several economically important traits, whose weighting coefficients are estimated so as to maximize the correlation between the selection index and the genotypic aggregate. The genotypic aggregate is established by another linear combination involving genetic values weighted by their respective economic values. Index of Pesek and Baker: it is a selection index based on the desired gains, which are easier to define. The b's coefficients are calculated according to the importance established by breeders in the specification of the desired gains in each trait. Classic Index of Mulamba and Mock: This index ranks genotypes, initially, for each trait, by assigning absolute values to those presenting the best performance. Finally, the values assigned to each trait are summed, yielding the sum of the ranks and indicating the classification of genotypes. The smaller the sum, the better the performance of a genotype for the various traits, which results in an additional measurement. Selection Index of Williams: This 
selection index, often called Base Index, is a linear combination of traits of interest in breeding, in which the economic weights are the weight coefficients of the index. It avoids the use of variance and covariance matrices, as demonstrated below:

$I=a_{1} x_{1}+a_{2} x_{2}+\ldots . .+a_{n} x_{n}=a^{\prime} X \quad$, where: $I=$ selection index; $a_{i}=$ economic weight attributed to the trait $i, 2$, so that $i=1, \ldots, n ; a^{\prime}=$ vector of the economic weights; $x_{i}=$ average of the trait, so that $i=1, \ldots, n$; and $\mathrm{X}=$ vector of the averages of the $\mathrm{n}$ traits included in the index.

\section{RESULTS AND DISCUSSION}

For the analysis of variance, in the first agricultural year, there was no significant effect $(\mathrm{P}>0.01)$ for the trait Brix PE. The other traits analyzed were significant.

The traits NC, Brix PE and Brix PT presented a significant effect at $5 \%$ probability by the F test, while DMC did not present significant effect at $5 \%$ probability by the $\mathrm{F}$ test. Thus, it is possible to achieve gains by selection, especially with the potential of the use of selection indices.

Brix PT presented the lowest coefficient of variation $(\mathrm{CV} \%)$ in the first year, $8.72 \%$, and Brix, in the second year, with $5.82 \%$. DMC presented the highest coefficient of variation, $31.23 \%$, and $\mathrm{NC}$, $26.52 \%$. The smaller is the coefficient of variation of a trait, the greater is the experimental accuracy. The high coefficients of variation can be interpreted with low experimental precision, which affects the inferences that can be made for the observed traits (BARBOSA et al., 2005).

In the joint analysis of data, for the source of variation year, a significant difference was observed at $1 \%$ probability by the $\mathrm{F}$ test for the three traits analyzed. It demonstrates that the environments (agricultural years) were considered satisfactorily different for generating differences among the traits under analysis.

Traits Brix PE and Brix PT presented significant differences for the sets, which demonstrate efficiency and the need of using randomized block design, with division into sets, in an experiment with many treatments. The absence of this division could produce variations and lead to losses of accuracy in the experiments.

The trait Brix PE showed significant differences, considering the year $\mathrm{x}$ set interaction ( $\mathrm{YxS}$ ). It indicates that the genotypes, randomly distributed in the sets, showed phenotypic changes stimulated by edafoclimatic changes in the environments.
For the source of variation genotype within set (Genot/set), traits DMC, Brix PE and Brix PT showed significances at $1 \%$ probability by the $\mathrm{F}$ test. It reveals the occurrence of genetic variability that can be explored in future stages of the breeding program for this culture and allows progress in selection.

A significant value was found for genotype $\mathrm{x}$ environment interaction within the set $(\mathrm{ExG} / \mathrm{S})$ for the trait Brix PT, demonstrating that the families did not maintain the same response for such phenotypic trait in both environments (planting years), due to climatic changes occurring in the two agricultural years (2008 and 2009).

The presence of significant interaction between the genotypes and years evaluated indicates that, besides genetic and environmental effects, the effect of genotype $x$ year interaction affects the results. This means that the response of a particular genotype in several years may change, which complicates both selection and recommendation for planting, according to BARBOSA et al. (2004). Genetic variability, the selection method adopted, population size and effects from the environment are factors that affect the rate of increase in favorable gene frequencies.

The lowest coefficient of variation $(\mathrm{CV}$ \%) was observed in PE Brix, 6.67\%. DMC presented the highest coefficient of variation, $9.50 \%$. The field experiment showed good stability and reliability in data measurement, since the values of the coefficients of variation are below $20 \%$, as suggested by BARBOSA et al. (2005).

The success of any breeding program depends mainly on the amount of genetic variability in the base population to be exploited, the heritability of the trait that is being improved and the extent of genetic gain possible for the trait. The estimates of the genetic parameters of the first stage of selection (T1) of the RIDESA/UFRRJ Breeding Program in partnership with UENF can be seen in table 1 .

Knowledge about genetic parameter estimates allows breeders to produce useful information on the different traits evaluated in the population under study. It can also indicate the most appropriate selection strategy and lead to successful prediction in breeding programs. Low rates of genetic and phenotypic variances among genotypes were observed for all three traits under analysis. The genetic variation coefficients were more significant.

Estimates of genetic variation coefficient $\left(\mathrm{CV}_{\mathrm{g}}\right)$ give breeders information relative magnitude of the changes that can be obtained through selection in a breeding program. All three traits exhibited high $\mathrm{CV}_{\mathrm{g}}$ values, which indicate good chances of success in breeding programs aiming to select these traits. 
The $\mathrm{CV}_{\mathrm{g}} / \mathrm{CV}_{\mathrm{e}}$ ratio, known as variation index, can provide information on the real situation of each trait aimed at breeding. The three traits evaluated expressed $\mathrm{Iv}<1$, which is a strong parameter to be considered. If it is low, limited selection will be achieved (VIANA et al., 2012). Similarly, SINGH et al. (1981) studied 48 varieties of sugar cane and observed that the $\mathrm{CV}_{\mathrm{g}} / \mathrm{CV}_{\mathrm{e}}$ ratio was lower than 1 for all traits analyzed.

In the early stages of selection, the strong effect of the environment on the genotypes of sugar cane evaluated is responsible for the low heritability estimates found in these stages (SKINNER et al., 1987; MATSUOKA et al., 2005). It makes individual selection less efficient, compared to the subsequent selection stages.

Heritability expresses the trustability of the phenotypic value as a guide to the genetic value, or the degree of correspondence between phenotypic value and genetic value. In other words, it measures the reliability of the measured phenotype value in predicting the true genotypic value.

In stage T1, PEDROZO et al. (2009) obtained heritability values for the traits diameter and Brix of 0.47 and 0.66 , respectively.For the traits diameter and Brix, for example, the estimates, considering families, ranged from 0.70 to 0.71 , and from 0.53 to 0.90 , respectively. Therefore, the estimates reported by these authors were similar to those found in this study, for the traits diameter and Brix. Selection based on the average of families is more efficient than that based on individual plants, when traits of low heritability are considered. PEDROZO et al. (2011) reported that heritability estimates based on averages of families were generally higher, compared to its estimates in individual plants for the six traits studied. Since selection for sugar productivity is inefficient in the first clonal generations, breeding programs have conducted parallel selection studies based on the selection of superior families (BARBOSA et al., 2004; BARBOSA et al., 2005).

Table 1 contains estimates of the predicted percentage gains for the selection index of Mulamba and Mock, Smith and Hazel, and shows these gains for the indices of Pesek and Baker and Williams, using the genetic variation coefficient $\left(\mathrm{CV}_{\mathrm{g}}\right)$, genetic standard deviation $\left(\mathrm{DP}_{\mathrm{g}}\right)$, variation index $\left(\mathrm{CV}_{\mathrm{g}} / \mathrm{CV}_{\mathrm{e}}\right.$ $=\mathrm{Iv}$ ) and heritability $\left(\mathrm{h}^{2}\right)$ as economic weights. The selection was carried out in the traits DMC, P, Brix $\mathrm{PE}$ and Brix PT. The predicted percentage gains for the selection index of Mulamba and Mock, for all economic weights, provided simultaneous positive values for all traits. However, for the index of Pesek and Baker, no estimates of predicted simultaneous gains were obtained in the traits $\mathrm{P}(-51.52 \%)$ and Brix PT (-0.3\%), using all the economic weights. Thus, these gains were not satisfactory.

Table 1 - Estimates of genetics parameters (genotypic variance $\left(\sigma_{\mathrm{g}}^{2}\right)$ ), phenotypic variance $\left(\sigma_{\mathrm{f}}^{2}\right)$, heritability $\left(\mathrm{h}^{2}\right)$, genetic variation coefficient $\left(\mathrm{CV}_{\mathrm{g}}\right)$, experimental variation coefficient $\left(\mathrm{CV}_{\mathrm{e}}\right)$, genetic variation index $\left(\mathrm{Iv}_{\mathrm{g}}\right)$, standard deviation $\left(\mathrm{Dp}_{\mathrm{g}}\right)$ and the average, and estimates of percentage gains by selection indices of the traits evaluated, in 68 full-sib families of sugar cane, using the average of the two agricultural years.

\begin{tabular}{|c|c|c|c|c|c|c|c|c|}
\hline Traits & $\sigma_{g}^{2}$ & $\sigma_{f}^{2}$ & $\mathrm{~h}^{2}$ & $\mathrm{CV}_{\mathrm{g}}$ & $\mathrm{CV}_{\mathrm{e}}$ & $\mathrm{Iv}_{\mathrm{g}}$ & $\mathrm{Dp}_{\mathrm{g}}$ & Average \\
\hline DMC & 1.91 & 2.79 & 0.68 & 5.72 & 9.50 & 0.60 & 1.38 & 24.21 \\
\hline Brix PE & 0.49 & 0.79 & 0.62 & 3.48 & 6.67 & 0.50 & 0.70 & 20.18 \\
\hline Brix PT & 0.83 & 1.16 & 0.71 & 5.20 & 8.07 & 0.65 & 0.91 & 17.52 \\
\hline \multirow[t]{2}{*}{ Traits } & ------- & --Mulam & Iock $^{(1)}$ - & ------. & ------- & ---Smith & $\mathrm{el}^{(1)}$ & ----- \\
\hline & $\mathrm{CV}_{\mathrm{g}}$ & $\mathrm{DP}_{\mathrm{g}}$ & Iv & $h^{2}$ & $\mathrm{CV}_{\mathrm{g}}$ & $\mathrm{DP}_{\mathrm{g}}$ & Iv & $h^{2}$ \\
\hline DMC & 3.92 & 3.35 & 4.73 & 4.73 & 5.34 & 5.34 & 5.34 & 5.34 \\
\hline $\mathrm{P}$ & 116.59 & 130.91 & 78.98 & 78.98 & 126.23 & 126.23 & 126.23 & 126.23 \\
\hline Brix PE & 0.44 & 0.29 & 0.57 & 0.57 & 0.28 & 0.28 & 0.28 & 0.28 \\
\hline Brix PT & 9.76 & 6.42 & 12.7 & 12.7 & 6.29 & 6.29 & 6.29 & 6.29 \\
\hline \multirow[t]{2}{*}{ Traits } & ------ & ---Pesek & $e r^{(1)}$ & -----" & & ---Wi & - & \\
\hline & $\mathrm{CV}_{\mathrm{g}}$ & $\mathrm{DP}_{\mathrm{g}}$ & Iv & $h^{2}$ & $\mathrm{CV}_{\mathrm{g}}$ & $\mathrm{DP}_{\mathrm{g}}$ & Iv & $h^{2}$ \\
\hline DMC & 8.38 & 8.38 & 8.38 & 8.38 & 2.58 & 2.58 & 2.68 & 2.68 \\
\hline $\mathrm{P}$ & -51.52 & -51.52 & -51.52 & -51.52 & 132.01 & 132.01 & 131.78 & 131.78 \\
\hline Brix PE & 0.01 & 0.01 & 0.01 & 0.01 & 0.23 & 0.23 & 0.26 & 0.26 \\
\hline Brix PT & -0.3 & -0.3 & -0.3 & -0.3 & 5.18 & 5.18 & 6.1 & 6.1 \\
\hline
\end{tabular}

(1)-Percentage of genetic gains by Selection index, $\mathrm{DMC}=$ average stem diameter, $\mathrm{P}=$ Weight of stem, Brix PE, Brix PT. 
The trait $\mathrm{P}$ achieved the highest predicted percentage gains, $132.01 \%$ for both, with the index of Willians, when the economic weights $\mathrm{CV}_{\mathrm{g}}$ and $\mathrm{DP}_{\mathrm{g}}$ were used; when the ecomonic weights Iv and $h^{2}$ were used, their value was $131.78 \%$. The predicted percentage gains for the selection index of Smith and Hazel, for all economic weights, provided simultaneous positive values for all traits.

PEDROZO et al.(2009) concluded that the multiplicative index showed the highest efficiency of selection of superior genotypes of sugar cane, which could increase the chances of success in breeding programs of this culture.

PILLAIE \& ETHIRAJAN (1993) estimated selection indices at different selection stages for sugar cane (Saccharum officinarum L.) population of biparental mating. In seedling stage, selection based on the index can lead to more efficient selection in successive clonal stages. These authors concluded that the selection index method was highly efficient for selecting superior genotypes with consistent performance in a hybrid population of sugar cane.

According to JACKSON (2005), the high economic value improve the content of sucrose in sugar cane, which explains base research on the causes of the low rates of gain, associated with the creation of alternative strategies. For this author, basic research should be carried out on parental clones and descendants in use, to evaluate breeding programs and provide accurate estimates of the main genetic parameters of additive genetic variation, narrow sense heritability and genetic correlations between traits for the production of cane, CCS (sugar content in commercial sugar cane derives from measurements of Brix, Pol and fiber), and other traits economically relevant. It was concluded that, the selection indices can be determined, based on these parameters, to maximize the rate of genetic gain of economic value, for use in modern breeding programs.

In this study, the index of Mulamba and Mock and the index of Smith and Hazel allowed superior simultaneous gains, which were also better distributed among all traits assessed. The following families and their respective parents were selected: 41(SP 85-3877 X RB 961005), 45 (RB 957610 X RB 93522), 46 (RB 896342 X RB 92508), 4 (RB 863129 X SP 83-2847), 17 (SP 80-3280 X SP 70-1284), 58 (RB 945065 X RB 912695), 18 (RB 965911 X SP 83-2847), 66 (RB 915141 X SP 89-1115), 3 (RB 92606 X SP 83-2847), 22 (RB 925345 X RB 91514), 51 (RB 9557 X RB 72454), 38 (RB 945954 X RB 957712), 52 (Co 434 X RB 946915), 35 (RB 957712
X RB 993522), 34 (RB 936001 X RB 965586), 7 (RB 72454 X RB 855035), 21 (SP 80-3280 X RB 947501), 48 (SP 71-6949 X RB 83102), 37 (RB 951015 X RB 957712), 27 (RB 92606 X RB 971537) and 49 (SP 83-2847 X RB 855206).

\section{CONCLUSION}

The use of selection indices and the estimation of genetic parameters in full-sib families in sugar cane allowed the selection of families with higher gains distributed in all variables assessed and the continuation of the breeding program under development. Not so far this knowledge brings more effective contribution for the models and analysis for selection superior genotypes.

\section{REFERENCES}

AMARAL JÚNIOR, A.T. et al. Improvement of a popcorn population using selection indexes from a fourth cycle of recurrent selection program carried out in two different environments. Genetics and Molecular Research, v.9, n.1, p.340-347, 2010. Disponível em: <http://www.funpecrp.com.br/gmr/year2010/vol91/pdf/gmr702.pdf $>$. Acesso em: 13 out.2013. doi: 10.4238/vol91 gmr702.

BARBOSA, M.H.P. et al. Use of REML/BLUP for the selection of sugarcane families specialized in biomass production. Crop Breeding and Applied Biotechnology, v.4, p.218-226, 2004. Disponível em: <http:/ainfo.cnptia.embrapa.br/digital/bitstream/ item/38358/1/sp5008.pdf>. Acesso em: 12 nov. 2012.

BARBOSA, M.H.P. et al. Selection of sugarcane families and parents by REML/BLUP. Crop Breeding and Applied Biotechnology, v.5, p.443-450, 2005. Disponível em: <http:// www.sbmp.org.br/cbab/siscbab/uploads/bd6b8337-526d-551d. pdf $>$. Acesso em: 23 set.2013.

BARBOSA, V.S.B. et al. A brief report on sugarcane breending program in Alagoas, Brazil. Crop Breeding and Applied Biotechnology, v.2, p.613-616, 2002. Disponível em: <http:// www.sbmp.org.br/cbab/siscbab/uploads/c8128f42-578c-c0df. pdf $>$. Acesso em: 13 agost.2013.

COX, M.C.; HOGARTH, D.M. The effectiveness of family selection in early stages of a sugarcane improvement program. In: AUSTRALIAN PLANT BREEDING CONFERENCE, 10., 1993, Bundaberg. Proceedings. Brisbane: Watson Ferguson, 1993. p.53-54.

CONAB COMPANHIA NACIONAL DE ABASTECIMENTO). Acompanhamento da Safra Brasileira Cana-de-Açúcar, Safra 2012/2013, primeiro levantamento, abril/2012. - Brasília, 2012. Disponível em: <www.conab.gov.br>. Acesso em: 29 set. 2012.

CRUZ, C.D. et al. Modelos biométricos aplicados ao melhoramento genético. Viçosa: UFV, 2004. 480p.

DAROS, M. et al. Recurrent selection in inbred popcorn families. Scientia Agricola, v.61, n.6, p.245-250, 2004. Disponível em: <http:// www.scielo.br/pdf/sa/v61n6/a08v61n6.pdf>. Acesso em: 18 set.2012. 
GRANATE, M.J. et al. A análise de fatores na predição de ganhos por seleção em milho (Zea mays L.). Acta Scientiarum, v.23, n.5, p.1271-1279, 2001.

JACKSON, P.A. Breeding for improved sugar content in sugarcane. Field Crops Research, v.92, p.277-290, 2005. Disponível em: <http://www.sciencedirect.com/science/article/pii/ S0378429005000365>. Acesso em: 10 set. 2013.

MATSUOKA, S. et al. Melhoramento da cana-de-açúcar. In: BORÉM, A. (Ed.). Melhoramento de espécies cultivadas. Viçosa, MG: UFV, 2005. p.225-274.

PEDROZO, C.A. et al. Eficiência de índices de seleção utilizando a metodologia reml/blup no melhoramento da cana-de-açúcar. Scientia Agraria, v.10, n.1, p.31-36, 2009.

PEDROZO, C.A. et al. Repeatability of full-sib sugarcane families across harvests and the efficiency of early selection. Euphytica, n.182, p.423-430, 2011. Disponível em: <http://link.springer.com/ article/10.1007/s10681-011-0521-z\#page-1>. Acesso em: 23 out. 2013. doi: 10.1007/s10681-011-0521-z.

PILLAI, S.V.; ETHIRAJAN, A.S. Selection indices for sugarcane improvement at three stages of selection. Euphytica, v.71, p.155-159, 1993. Disponível em: <http://link.springer.com/ article/10.1007/BF00023479\#page-1>. Acesso em: 21 nov. 2013.
SILVA, M.G.M. et al. Seleção recorrente intrapopulacional no maracujazeiro amarelo: alternativa de capitalização de ganhos genéticos. Ciência e Agrotecnologia, v.33, n.1, p. 170-176. 2009. Disponível em: <http://www.scielo.br/pdf/cagro/v33n1/ v33n1a24.pdf>. Acesso em: 12 set. 2012. doi.org/10.1590/S141370542009000100024 .

SILVA, F.F. et al. Selection and estimation of the genetic gain in segregating generations of papaya (Carica papaya L.). Crop Breeding and Applied Biotechnology, n.8, p.1-8, 2008. Disponível em: <http://www.sbmp.org.br/cbab/siscbab/uploads/ bd6b9df0-111c-2056.pdf>. Acesso em: 21 out. 2012.

SILVEIRA, L.C.I. et al. Sugarcane: cultivar RB937570. Crop Breeding and Applied Biotechnology, n.12, p.160-163, 2012. Disponível em: <http://www.sbmp.org.br/cbab/siscbab/uploads/ c8eb9792-b1c3-8795.pdf>. Aceso em: 22 nov. 2012.

SINGH, H.N. et al. Selection parameters in sugarcane. Indian Journal Agricultural Sciences, v.51, n.8, p.562-566, 1981.

SKINNER, J.C. et al. Selection methods, criteria, andindices. In: HEINZ, D.J. (Ed.). Sugarcane improvement through breeding. Amsterdam: Elsevier, 1987. p.409-453.

VIANA, J.M.S. et al. Combined selection of progeny in crop breeding using best linear umbiased prediction. Candian Journal of Plant Science, n.92, p.553-562, 2012. Disponível em: $<$ http://pubs.aic.ca/>. Acesso em: 21 out. 2013. doi/pdf/10.4141/cjps2011-110. 